深部坑道維持対策ししてそで巻充填の強度の強化( 自然発 火防止を兼祆る), 坑道枠裏の覆工技術 (赤平), 口ック ボルトによる坑道狭小化防止技術の開発に関する研究等を 行なつている。

石炭技研の自主研究として圧縮試験による坑道および切 羽周辺の地圧挙動に関する研究, 切羽用の噴霧併用式小型 冷風機の試作実用化試験等に関する研究を行なつた。

日本に扔ける鉱山関係の唯一の国立研究所である公害資 源研究所では, 昨年度の両支所の改名並びに北海;道石炭鉱 山技術研究センターの 1 課増設に伴い, 前述のガス突出の 機構解明に関する研究を北海道研究センターで行なうよう になつた。また坑内火災拡大防止に関する研究は昨年に引 続き九州研究センターで行なつている。これらは石炭およ び石油対策特別会計による特別研究である。

研究所の特別研究および経常研究も昨年に引続き行なわ れている。主なる研究テーマとしては，(1)地圧対策として 大型地層模型試験装置による地圧に関する研究, 電磁波に よる地層内探査については石灰石鉱山(秩父セメント)で現 場実験を行なつた。ガス突出予知の基礎的研究として石炭 化度の変化と突出物との相関性について検討を加えている。 (2)火炎 - 爆破防止対策としては自然発火の早期発見のため のアルカン比計の試作, メタンのガスレャーの然焼爆発伝 ぱに関する研究。(3)発破保安としては炭鉱用含水爆薬の性 能とその安全性に関する研究を行なつている。(4)総合ガス 保安対策として坑内ガス災害予知システムの開発を進め, 本年度は現場試験 ( 赤平炭鉱) に入つた。この他, 経常研 究として, 昨年に引続いてディーゼル機関の炭鉱坑内への 適用化のための基礎研究, 安全素子を応用した本質安全電 力増の研究等 7 テーマについて研究が行なわれている。石 炭技術研究との共同研究として払跡の熱気流の挙動, 試験 炭鉱において, 効果的な発破法の 2 テーマについて研究を 行なつた。
国際交流としては前述の項で述べたが，その他に公害資 源研究所では海外研究協力として, 本年度改めて韓国資源 開発研究所と保安技術に関しての研究協力を向う 3 年間行 なうことになうたこのため, 日本側から当研究員 2 名, 韓 国側から 3 名の研究員の交流が行なわれた。

保安センターは本年で 11 年目を迎元, 鉱山学働者の保安 教育, 救護隊員の訓練と養成に積極的に取り組んでいる。 その他に労衝安全衛生法に関連してじん肺 (粉じん) 対策 委員会, さく岩機振動障害対策委員会等が設置されそれぞ れ作業環境改善に努めている。

\section{5. 石炭利用技術}

政府はサンシャイン計画 (予算約 8,129,000千円) の中 において，化石エネルギー源である石炭を，ガス，電気お よび液体に限定し，エネルギーとして利用する技術の開発 が行なわれている。

すなわち, 石炭のガス化技術として高カロリーガス製造 技術, 低カロリーガス化発電技術, プラズマガス化技術を， また石炭夜化技術として直接夜化技術, 溶剂処理液化技術, ソルボリシス液化技術の開発を対象として進めている。石 炭利用関係の予算は約 1,440,000千円で, 国立研究機関は 特別研究として, また石炭技研, 業界には委託事業として 助成している。

この他, 石炭の直接利用として, 石炭技術研究所では, 直接利用技術として, 石炭火力用乾式脱硝技術の研究開発, 流動床燃焼技術の研究開発, 石炭・油混合燃料技術の研究 開発 (電力用燃料, 他産業用然料), 加工利用技術として, 微粉炭・褐炭の脱水・輸送・貯蔵等技術 ( 微粉炭空気輸送 試験, 褐炭利用技術の研究開発, 下廃水処理への利用とス ラッジ炭の燃料化技術の研究開発, 成形コークス製造技術 の研究開発を, 1978 年度に開始した。

\section{ま えがき}

昨年と同じく，掘進機には新製品が見られなかつたが， 盲立坑掘り上り用の大口径さく孔機の新機種が開発された。 またロックボルトの普及に伴い, ロックボルト用のさく孔・ 打設装置の開発が行なわれた。

炭鉱の切羽機械化のための新機種の試作・開発が活発 に行なわれた他, 自動化·遠隔操作化設備の試作 ·開発が, さく孔，運搬部門で盛んに行なわれている。

\section{1. さく孔および掘進機械}

さく孔の分野では，最近土木トンネルでも注目を沿びつ つあるロックボルトによる支保作業の合理化のため, ロッ クボルト打設機の開発が試みられ，一応の成果をあげた。 また全自動化さく孔装置の 1 号機が納入された他, 大口径 さく孔機による立坑切上の無人化に大きな進展がみられた。 三井金属鉱業神岡鉱山では, 従来の坑木または鋼材によ る三つ枠を施工していた岩艋に対しても，パターンボルティ ングと金網張との組合せで支保することとし，ホイール式 の積込・運般機であるK LD M- $5 \mathrm{~N}$ 型の車体に, リフト ジャンボのブームおよびさく岩機をとりつけ，さらに油圧 による可動作業台を装備したボルトセッティング専用車を 


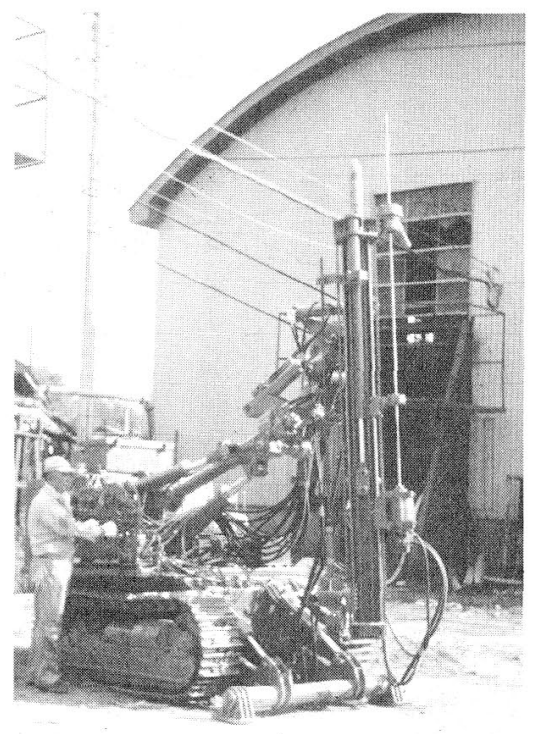

第 1 艮

ボルトセッター

第 1表 ボルトセッターの主要諸元

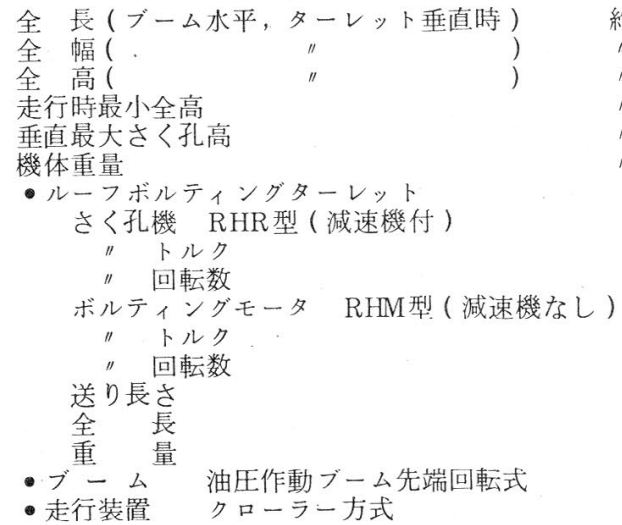

約 $3,700 \mathrm{~mm}$

"1,610"

" 3,200 "

" 2,030 "

" 4,600 "

" $8,500 \mathrm{~kg}$

$20 \mathrm{kgm}$ $650 \mathrm{rpm}$

$20 \mathrm{kgm}$ $625 \mathrm{rpm}$ $2,240 \mathrm{~mm}$ $2,906 \mathrm{~mm}$ $950 \mathrm{~kg}$

開発し，ボルト打設の大幅な省力化に成功した。

石炭技術研究所では，さく孔からボルト插入までのプロ セスを自動化するために，ボルトセッターを開発し，北炭 夕張新炭鉱において現場試験を行ない，ロックボルト施工 能率が従来の約 3 倍にあたる 40 木/方程度まで向上する ことを確認した。本機は三井造船アイムコのM E 6424 型 サイドダンプローダーの車体に，全旋回機構付きブームお よびセコマ社のルーフボルトターレットを装備したもので, 外観を第 1 図に，仕様を第 1 表に示す。

東洋工業は，国産初の全自動さく孔機A D 78型を試作 し，10月末，三井金属鉱業神岡鉱１以納入した。本機は 電子技術を導入して, 油历と圧気の回路の作動を制御し, 切羽全体のさく孔作業を自動的に行なうようにしたもので ある。ジャンボの本体を切羽にセットして起動させれば， 予め記憶させたパターンに従つて，さく孔ポイントに向つ てのブームとセルの移動, 位置決め, そのポイントのさく 孔, さく岩機の後退に至る全過程が自動的に行なわれる。 仕様を第 2 表に示す。

三井造船アイムコは, 排ガス対策を強化して, 707 型 ランドメイトを母体とする坑内用自走式 2 ブームジャンボ
第 2表 AD78 型全自動さく孔装置の仕様

- 制御装置：

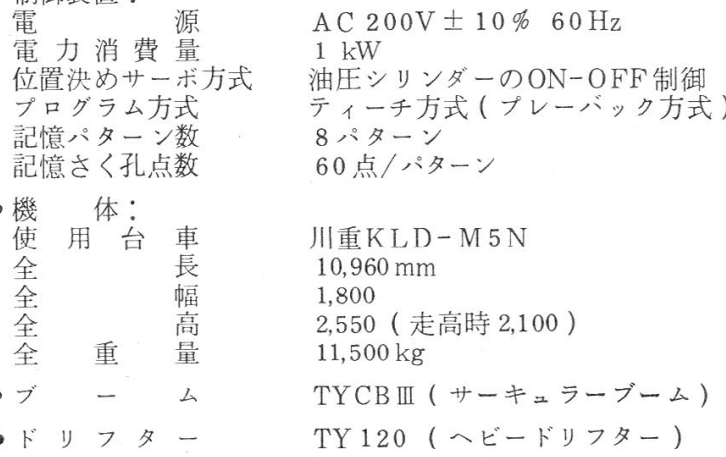

を発売した。三井ドイッ空冷エンジンに独特の排気処理装 置を搭載したものである。

古河鉱業は, 油压ドリフター（HD 100$)$ を搭載したホイ ールタイプの J TH-2 型 2ブームジャンボを，クローラータ イプに改造し，新たにリフトおよびスライド可能な作業足 場を付加して，全油圧式クローラージャンボ ( JCH-2 型 ) として発売した。

三井金属鉱業神岡鉱山では，上部坑道から下部坑道に向 けてパイロット孔を掘削し，このパイロット孔を利用して 大口径のリーミングカッタを下部坑道から上部坑道に引上 げるタイプの大口径さく孔機であるインガーソルランド社 のRB H-6 A型を導入し, 直径 $1.88 \mathrm{~m}$ のレイズボーラ 切上りを, 約 $300 \mathrm{~m}$ (立坑 3 本) 施工した。ボタンタイプ のカッタを取付けたヘッドの断面が円弧状になつており, 切削中すべてのカッ夕に均等に荷重が分散されるので，力 ッタの消耗に好結果が得られるといわれている。第 2 㘠に カッタ㧍よびステムを示す。

同和鉙样と鈗研試錐は, 大口径の全断面立坑切上り掘削 機の共同開発に取組み，M S R M型の試作一号機を開発し， 同和鉱業松峰鉱山で実用化試験を行なつた。12月までに, 延べ $277.4 \mathrm{~m}$ （13立坑）の掘削を行ない, 直径 $1.4 \mathrm{~m}$, 深度 $30 \mathrm{~m}$ 程度の立坑切上りならば, 全断面の掘削と支保

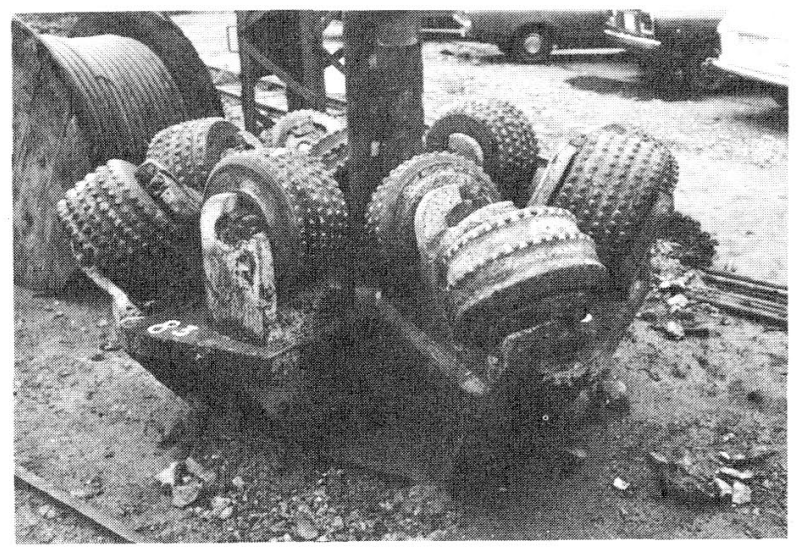

第 2図大口径さく孔機RBH-6A型のリーミンダカッタ (約 $300 \mathrm{~m}$ 掘削後)

日本鉱業会誌/951093('79-3) 111<15〉 


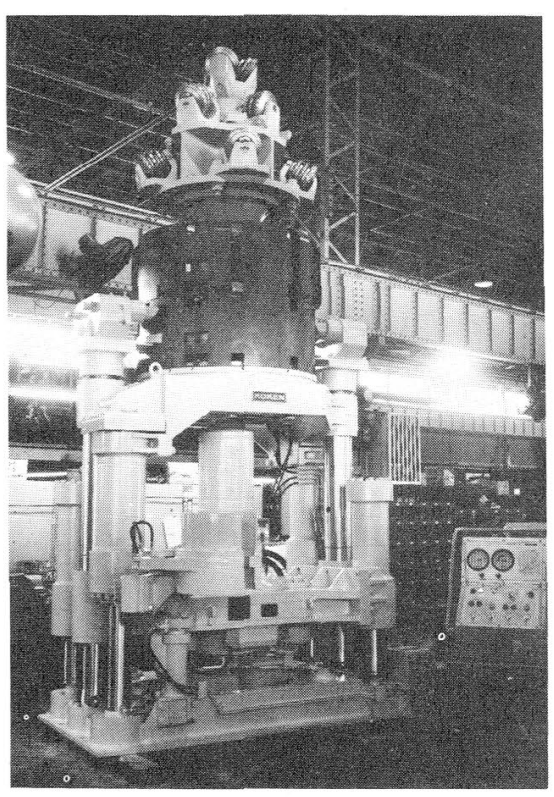

第了図 シールド式ブラインドレイズ ボーリングマシン

第了表 シールド式ブラインドレイズボーリングマシンの仕様

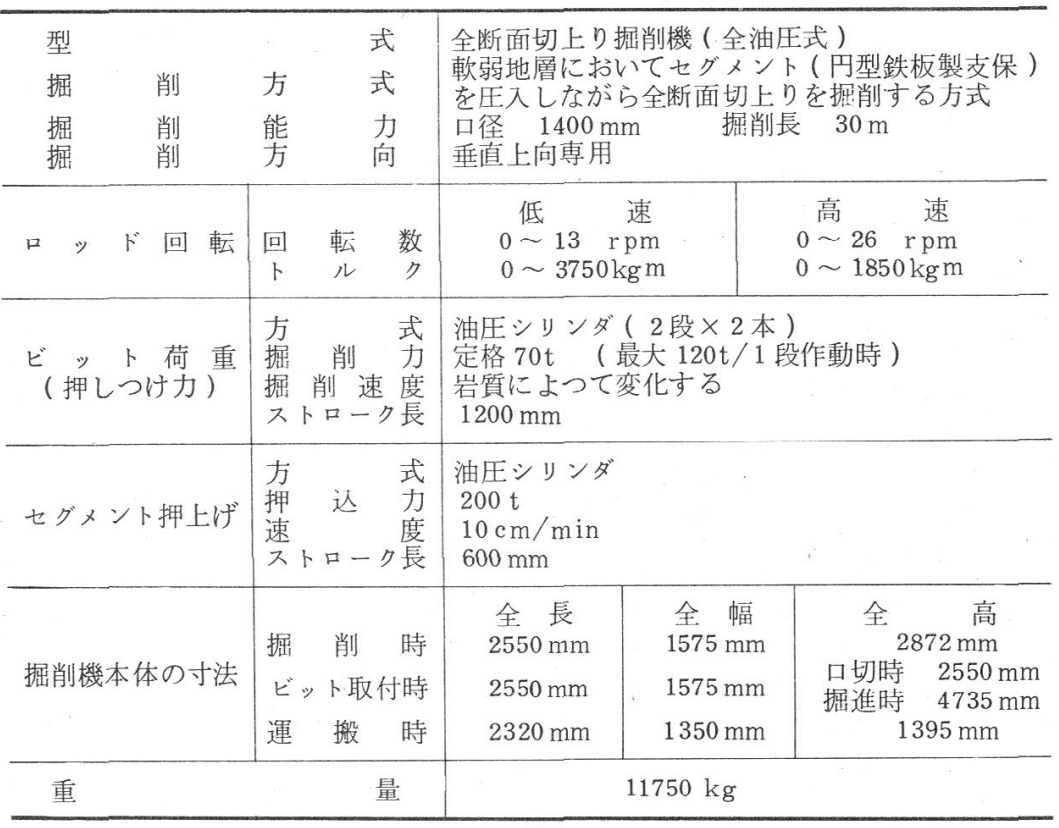

式全断面掘削用ビットに接続したロッドに油圧駆動で回転 力と推力を加え, 立坑全断面の掘削を行なうが，1 サイク ル $1 \mathrm{~m}$ ごとに，ターンテーブル上で円形鉄板製セグメント を組立て, 立坑内の既設セグメントと連結し, 油圧で押上 げるので, 軟弱地層へも適用できるとい方よう。第 3 表に 仕様を，第 3 四に外観を示す。

住友石炭赤平炭鉱では, 急傾斜の払座および風道掘進の ために，550 mm径のリングカッタ一を試作し, 石油薮井 機製 $\mathrm{P}-12-\mathrm{H}$ 型をさく孔機として，大口径切削を行ない， 一応の成果を揖さめた。

\section{2. 採炭機械・自走支保}

石炭技術研究所では, 採炭切羽深ステーブルの自走支保 化を図るため, 昭和 53 年度 石炭技術振興費補助金の交付 を受け，払跡袖巻充填作業を考慮した切羽端自走支保の開 発を行ない，1978年10月より池島炭鉣で現場試験を開 始した。この枠は袖巻充填の肩部用自走枠 ( 2 枠で 1 組) と袖巻充填の前部用自走枠（2枠で 1 組）で構成している。

肩部用白走枠は, 切羽面自走枠の後に配置しチェーンで 連結している。この枠はスライドカッペを内蔵した先端カ ッペおよび後端カッペを持ち，さらに肩側枠はずりの侵入 を防止するため, 側方カッペと側板を備えている。主な仕 様は, 最大高さ $2,600 \mathrm{~mm}$, 最小高さ $1,400 \mathrm{~mm}$, 枠受持 幅 $1,250 \mathrm{~mm}$, 建付荷重第 1 段 $25.7 \mathrm{t}\left(180 \mathrm{~kg} / \mathrm{cm}^{2}\right)$, 第 2 段 $45.9 \mathrm{t}\left(180 \mathrm{~kg} / \mathrm{cm}^{2}\right)$, 降縮荷重第 1 段 $82 \mathrm{t}$ ( 573 $\left.\mathrm{kg} / \mathrm{cm}^{2}\right)$, 第 2 段 $70 \mathrm{t}\left(275 \mathrm{~kg} / \mathrm{cm}^{2}\right)$ となつており, シ ールドタイプである。

前部用自走枠は, 切羽面自走枠の役目をする前方枠部分 と充填間天盤を支持する後方枠部分からなつており, 前方 枠部分は普通のシールド枠と同じであるが，後方枠部分は

簡易型自走枠で, 前カッペ, 後カッペ, 前方枠と連結する ガイド板および鉄柱からなる。この朹の前方枠部分の主な 仕様は, 最大高さ $2,580 \mathrm{~mm}$, 最小高さ $1,825 \mathrm{~mm}$, 朹受 持幅 $1,100 \mathrm{~mm}$, 建付荷重 $25.6 \mathrm{t}\left(180 \mathrm{~kg} / \mathrm{cm}^{2}\right)$, 降縮荷 重 $60 \mathrm{t}\left(420 \mathrm{~kg} / \mathrm{cm}^{2}\right)$ で, 後方枠部分の主な仕様は, 最大 高さ $2,664 \mathrm{~mm}$, 最小高さ $1,814 \mathrm{~mm}$, 枠受持幅 $550 \mathrm{~mm}$, 建付荷重 $17.1 \mathrm{t}\left(180 \mathrm{~kg} / \mathrm{cm}^{2}\right)$, 降縮荷重 40 t ( $420 \mathrm{~kg}$ $\left./ \mathrm{cm}^{2}\right)$ となつている(第 4 図参照)。

三池炭鉱三川鉱では，深部移行が進むにつれ，次第に薄 層化の傾向にあり, その対策として, ホーベルと自走支保 の組合せを計画し，1978 年 6 月より，三井三池製作所製 の薄層用自走支保

( MKSP-F SH 40 型 $\mathrm{MK} 1$ シールド枠) と西独ウェストファリ ア製のグライトホーべ ル(アウスレーガー制 御装置を含む) を導入 した。

この枠の主な仕様は， 最大高さ $1,800 \mathrm{~mm}$, 最小高さ $750 \mathrm{~mm}$, 枠 受持幅 $1,300 \mathrm{~mm}$, 建 付荷重第 1 段 $53.4 \mathrm{t}$, 第 2 段 $99.4 \mathrm{t}$, 降縮荷 重第 1 段 120 t (562 $\left.\mathrm{kg} / \mathrm{cm}^{2}\right)$, 第 2 段 140 $\mathrm{t}\left(325 \mathrm{~kg} / \mathrm{cm}^{2}\right)$ とな つている(第5図参照)。 ホーベルの主な仕様

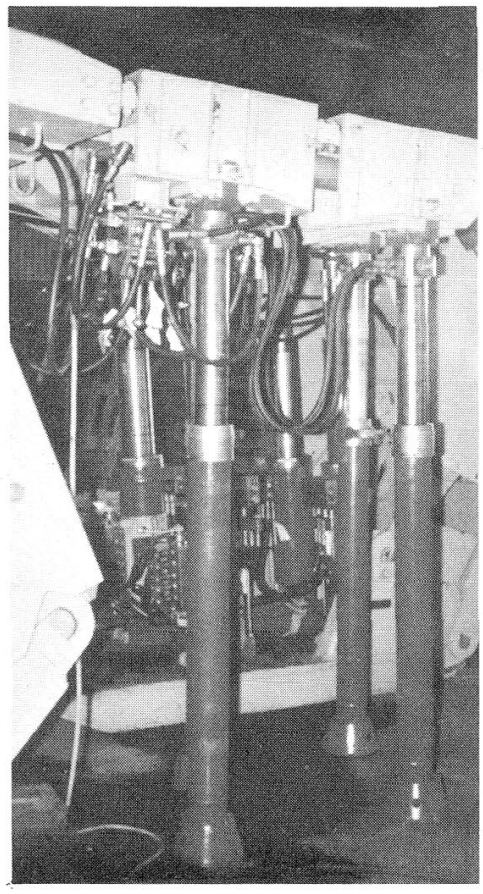

第 4 図切羽端用自走支保 


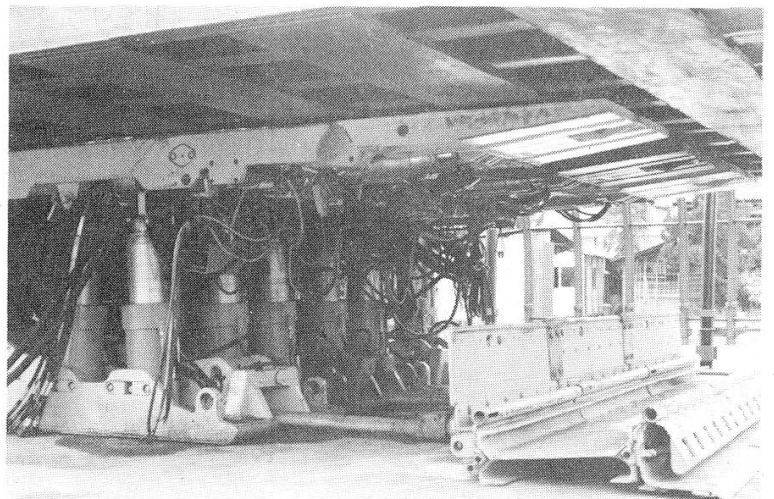

第 5図 MKSP-FSH40 型シールド自走支保

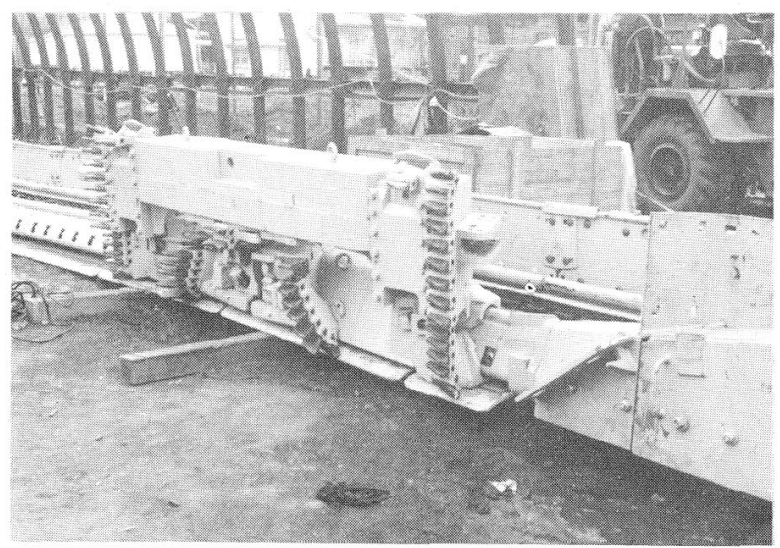

第6図 グライトホーベル本体

は, 本体長さ $3,060 \mathrm{~mm}$, 高さ $544 \sim 1,600 \mathrm{~mm}$, 幅 515 $\mathrm{mm}$, 速度 $34 \mathrm{~m} / \mathrm{min}$, モータ出力 $90 \mathrm{~kW} \times 2$, チェーン $26 \phi \times 92 \mathrm{~mm}$ である(第 6 図参照)。また，今回導入した アウスレーガー制御装置 (第 7 図参照) を用いるとコンベ ヤを常に水平に保つことがでさ，下盤調整が容易となり， 切削深さも増大するといわれている。

南大夕張炭鉱では，断層褶曲が多い中傾斜層切羽の自走 支保化を図るべく検討を進め，1978 年 3 月より西独ベュ リット社製チョックタイプ自走支保 2 枠の試験を実施した。 この枠の主な仕様は, 最大高さ $2,850 \mathrm{~mm}$, 最小高さ $1,300 \mathrm{~mm}$, 枠受持幅 $1,500 \mathrm{~mm}$, 建付荷重 $64.2 \mathrm{t}$ ( 300 $\left.\mathrm{kg} / \mathrm{cm}^{2}\right)$, 降縮荷重 $80 \mathrm{t}\left(360 \mathrm{~kg} / \mathrm{cm}^{2}\right)$ となつている (第 8 図参照)。

赤平炭鉱では, 急傾斜欠口充填払における保安, 坑木節 減および坑木搬入のための労働力の省略を目的として，日 本鉱機に軽量鉄柱の開発を依頼し，1978年 9 月より 2 種 類の軽量鉄柱を導入した。

この鉄柱の主な仕様は第 4 表に示すとおりである。 太平洋釧路炭鉱では，ルーム採炭の高能率化を図るため, 従来のアーチ型組枠にかえ, 軽量梁, 軽量鉄柱および枠回 収機を用いた新方式のルーム採炭を 1978 年 4 月より開始 した。

この軽量梁 (日本鉱機製) は I 型形状で $100 \mathrm{~mm} \times 114$ $\mathrm{mm} \times 5000 \mathrm{~mm}$, 重量 $67.8 \mathrm{~kg}$ のものと $100 \mathrm{~mm} \times 120 \mathrm{~mm}$

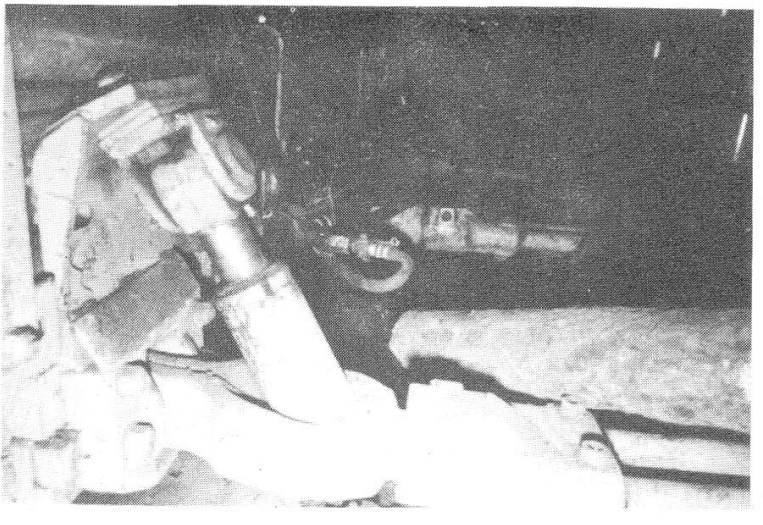

第 7 図 アウスレーガ制御装置

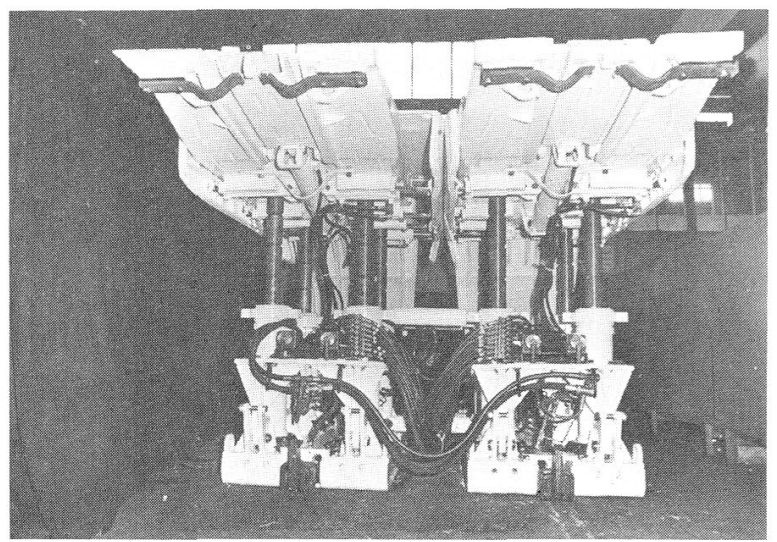

第 8 図 ベュリット社製チョックタイプ自走支保

$\times 7000 \mathrm{~mm}$ ，重量 $106.7 \mathrm{~kg}$ ののと 2 種類ある。

鉄柱としては，日本鎬機製 $35-\mathrm{AL}-2800-\mathrm{S}$ ( 降縮 荷重 $35 \mathrm{t}$ ) を使用している。

採炭機の 1 部品であるが，日本鉱機製強制散水ドラムお よびサイドプルロックピックが新製品として発売され, 北 炭夕張新炭鉱 (1978 年 12 月) , 北炭幌内炭鉱 (1978 年 2 月）等で使用開始された。

強制散水ドラムは，ピック 1 本に 2 個の散水口があり 1 個はチップ前面に，1個は後方に吹きつけることにより， 粉塵抑制, 着火防止等に効果をあげている。また, サイド プルロックピックは, ピックの新型で硬質パッキンにより 側面から張力を与え，ピックのガタをなくし，ピック寿命 の長期化を図るものである (第 9 図参照)。

\section{3. 積込機械，運搬機械}

キャタピラー三菱では石灰石鉱山や仯利，砕石の運搬に

第 4 表 急傾斜用軽量鉄柱

\begin{tabular}{c|c|c}
\hline 型 & $52145-01900$ & $52145-016000$ \\
\hline 最大長さ & $3,000 \mathrm{~mm}$ & $2,800 \mathrm{~mm}$ \\
最小長さ & $1,850 \mathrm{~mm}$ & $1,700 \mathrm{~mm}$ \\
調節長さ & $1,150 \mathrm{~mm}$ & $1,100 \mathrm{~mm}$ \\
建付荷重 & $13.6 \mathrm{t}\left(120 \mathrm{~kg} / \mathrm{cm}^{2}\right)$ & $13.6 \mathrm{t}\left(120 \mathrm{~kg} / \mathrm{cm}^{2}\right)$ \\
降縮 荷重 & $30.0 \mathrm{t}\left(265 \mathrm{~kg} / \mathrm{cm}^{2}\right)$ & $30.0 \mathrm{t}\left(265 \mathrm{~kg} / \mathrm{cm}^{2}\right)$ \\
重 & $50 \mathrm{~kg}$ & $57 \mathrm{~kg}$ \\
\hline
\end{tabular}

※両者共ポンプ外装タイプである。 

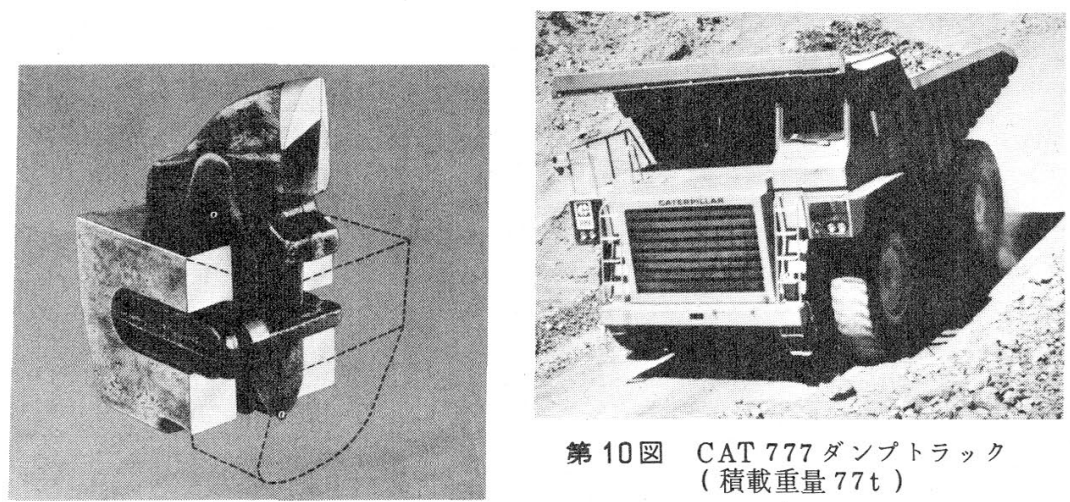

(積載重量 $77 \mathrm{t}$ )
CAT 980 C ホイルローダは総重量 $25,050 \mathrm{~kg}$, バケット容量 $4.0 \mathrm{~m}^{3}$, エ ンジン出力 $274 \mathrm{PS}$ で, CAT $992 \mathrm{C}$ ホイルローダーは総重量 $85,150 \mathrm{~kg}$, バケット容量 $9.6 \mathrm{~m}^{3}$, エンジン出力 700 PSの超大型となつている。いず れも特にバケット引起し力の増強が考 慮されている。

小松製作所でも最大積載量 $120 \mathrm{t}$ の HD 1200 型ダンプトラックを新製し た（第11図参照）。本機㥀流直巻 電動機により駆動されるが，電力は 1160 P S エンジン駆 動の 3 相交流ブラシュレス発電機により供給される。主な 仕様を第 5 表に示す。

また小松製作所では従来製作中のD $80 \mathrm{~A}-12$ 型, D 85

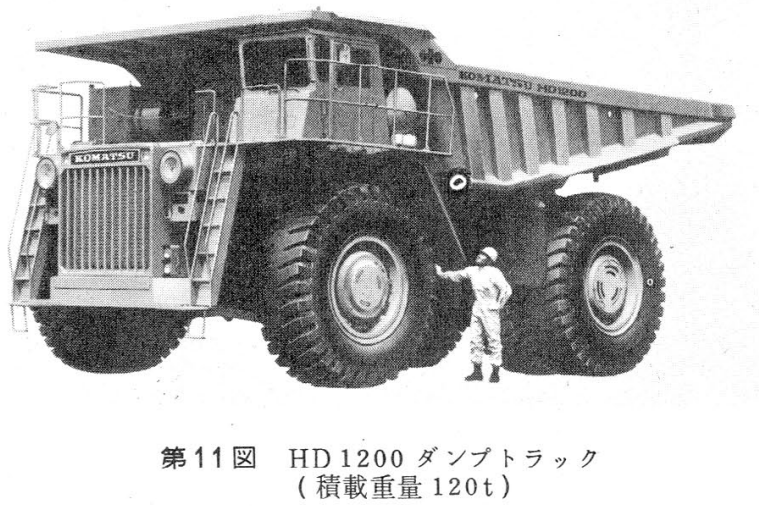

使用することを目的とした大型ダンプトラック 2 種および ホイルローダー 2 種を新製した。これらの内, CAT 769C ダンプトラックは最大積載量 $32 \mathrm{t}$, エンジン出力 456PS, 最高速度 $69 \mathrm{~km} / \mathrm{h}$ であり, CAT 777 ダンプトラック

(第 10 図参照) は最大積載量 $77 \mathrm{t}$, エンジン出力 882 $\mathrm{PS}$, 最高速度 $60 \mathrm{~km} / \mathrm{h}$ となつている。これらはいずれも フルオートマチックトランスミッションを備え, 制動機と して後輪湿式ディスクブレーキを装備している。また

第 5 表 HD 1200 ダンプトラックの 主要諸元

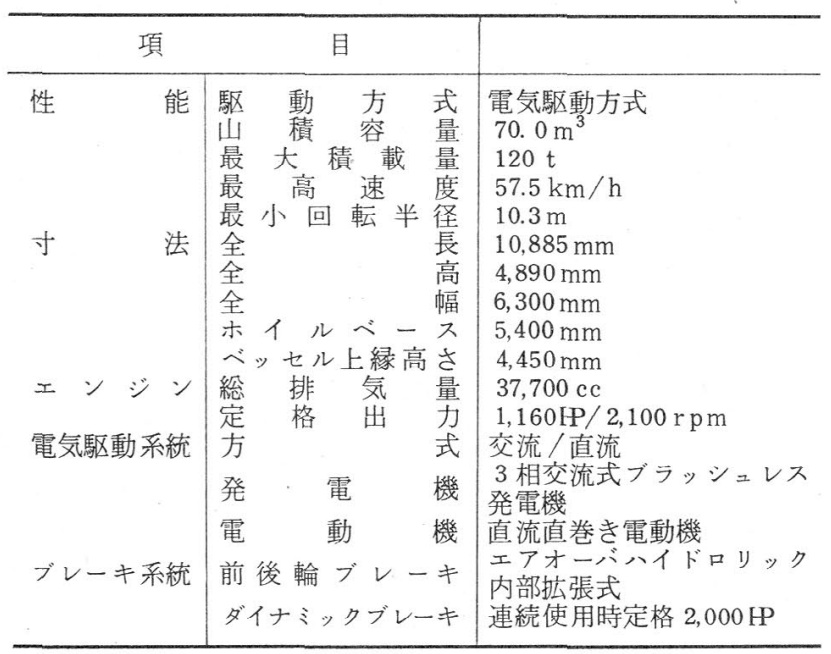

A-12型ブルドーザをモデルチェンジした D 80 A-18 型, D $85 \mathrm{~A}$ - 18型ブルドーザーを発表した。主な改良点 としてェンジン出力とブレード容量の増大がある。

これら大型機械の新製品とは逆に採炭切羽用簡易積込機 (第 12 図参照) が石炭技術研究所で試作され, 三菱南大 夕張炭鉱において現場試験が行なわれた。同研究所ではこ の試験結果を参考にして実用的な 2 号機の開発を行なつて いる。

また三井三池鉱業所三川鉱では, 冷房用クーラの移設と 材料運搬のために，西独ベコリット社製の I E - 140 型モ ノレールと, 西独シャーフ社製 $1140 \mathrm{E}$ 型モノレール各一 式を導入した。

\section{4. 遠隔および自動操作技術}

石炭技術研究所では三井芦別炭鉱第二坑副卸における斜 坑鉱車巻きに，自動化をとり入れた有線式遠隔操縱法を実 用化したが，本年はこのシステムの一部に超短波の微弱電 界 (送信周波数 $138.96 \mathrm{MHz}$ ) を使用した無線遠隔操縦方 式を取り入れ現場試験を行なつた結果, 実用化の見通しを 確認した。装置は無線携帯機, 2 分配器, 分散受信器およ

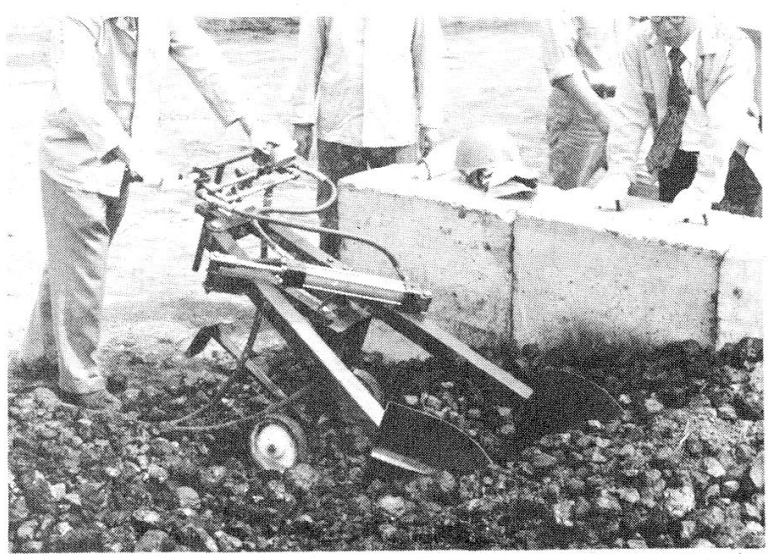

第 12 図採炭切羽用簡易積込機 
び固定局からなり，2分配器と分散受信器が対となつて斜 坑の適当な場所に約 $400 \mathrm{~m}$ 間隔て設置され, 固定局と配線 により連結されている。無線携帯機はさお取り夫が携行し 無線携帯機より発信される信号は固定局で選択され, リレ 一により鉱車巻きの自動運転回路を制御するものである。 この無線操縱装置の導入により斜坑のどの位置からでも巻 上機の制御が可能となり, 有線式ではスイッチを配置した $50 \mathrm{~m}$ おきでないと制御できなかつたことに比較して安全性 が向上した。

また同研究所では上述と同じような無線方式によりさお 取り夫と巻き運転手間の信号通信を斜坑の任意の位置で相 互に行なう実験を三菱南大夕張炭鉱三卸巻で完了し，実用 化の見通しを得た。

太平洋炭鉱では坑道掘進および採炭用として無線操䅠器 を装備した J OY コンティニアスマイナー $12 \mathrm{CM}$ (切削能 力 $8 \sim 12 \mathrm{t} / \mathrm{min}$, 自重 $41 \mathrm{t}$, 電動 3 段駆動式, 動力 490 P S )を導入した。

同和鉱業小䛀鉱業所では上向第 2 斜坑上部ビンにおける 鉱車への積込みが自動化された。従来は積込員か配置され て上部ビンのエプロンフィーダを運転して鉱石の積込みと 鉱車の入れ替えを行なつていたが，光電スイッチにより鉱車
の位置や積込状態を検出し, 電動ホイストを連動させる自 動積达制御設備が完成し積込員を廃止したものである。電 車運転手が空車を自動積込装置にセットすれば，実車を破 碎室に運転している間に鉱石の自動積込みが行なわれる。

東洋工業が三井金属神岡鉱業所に納入した TY A D -78 型全自動さく孔機はすでにさく孔機の項で述べたように起 動ボタンを押すだけであらかじめ定められた位置へのブー ムとセルの移動やさく孔等 1 切羽のさく孔作業が完了する まで全自動で操作が行なわれる。

\section{5.その他}

三井金属鉱業神岡鉱山では，従来からさく岩機の防振八 ンドルの開発が進められているが，今年はストーパのハン ドル中間に 2 個所防振材を組合せて, 防振効果を著しく向 上させることに成功した。

炭鉱では切羽用冷風機の使用が普及しているが，三菱高 島炭鉱では,フィン型冷却コイルを 2 次冷却に用い, この 冷却コイル入気口に冷却コイルの廃水を噴霧して, 1 次冷 却と防塵とを行なう新しい形式の切羽用冷風機を開発した。 その他, 神戸製鋼所では海外鉱山に新しい大型ジャイレ ートリクラッジャを数台輸出した。

選 鉱·選

炭

UDC 622. 7 "1978"

\section{まえがき}

主要金属価格の低迷と円高環境下で，1978年のわが国 の選鉱・選炭界は, 前年に等しい苦難を味わつた。

こうして，1）選鉱・選炭工場のいずれにおいてもごくわ ずかの例を除き設備投資がなされていない, 2) 国立研究機 関に扩り 1 次 - 2 次資源の高度利用に関する研究の推進, そいつた 1977 年の選鉱・選炭界の傾向が，そのまま78年 へと引続いている。

経済環境のきびしさを最も端的に示すニュースとしては, 尾去沢，松木および尾太釷業所の閉山にともなうそれぞれ の選鉱工場の閉鎖ならびに神岡鉱業所栃洞選鉱工場の休止 が挙げられる。しかし, 銅および鉛の建值は78年暮れを境 に，急激に值上がりしてきているので，国内鉱山の深刻な 採算も，ようやく曙光がみえてきた。これを反映した明る いニュースが，明年の展望読面を色どることを期待したい。

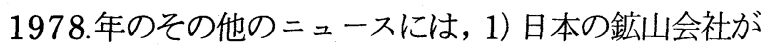
関係する海外の諸選鉱工場の順調操業のこと，2）船尾選鉱 工場 (石灰石) および釧路・赤平選炭工場における設備の 増強, 3) 選鉱・選炭操業の地道な改善, 4) 新技術・プラン ト輸出に関連するものなどがある。

\section{1. 選釷・選炭工場の動向}

\section{$1 \cdot 1$ 選釷工場}

1978 年 1 月 31 日をもつて, 松木鉱業松木鉱山が閉山 し,これに伴つて尾去沢選鉱工場における松木鉱受託処理 選鉱設備が閉鎖された。

同じく5月 31 日をもつて, 尾去沢鉱山尾去沢鉱業所が 閉止し，これに伴つて同選鈗工場が閉鎖された。

8 月 20 日には, 尾富鉱業尾太鉱山の閉山により, 同選鉱 工場が閉鎖された。

1977 年 9 月まで $1,600 \mathrm{t} /$ 日 操業を続けてきた三井金 属鉱業神岡鉱業所栃洞選鉱工場では, $1,050 \mathrm{t} /$ 日 処理へ 移行した後，段階的に縮小生産を行なつていたが，1978 年 12 月末 で休止することとなつた。これは亜鉛建値の下 落および円高ドル安に対処するための処置である。

一方石灰石鉱山のうち三井鉱山船尾鉱業所では, その選 鉱工場の設備増強を図り, 製品ホッパを $60 \mathrm{t}$ から 120 た 増強し, また破砕系統においても部品改造およびホッパ改 造を実施した。さらに環境対策として破砕設備にバグフィル ター $220 \mathrm{~m}^{3} / \mathrm{min}$ を設置し粉塺防止を図つている。

\section{$1 \cdot 2$ 海外の選鉱工場}

日本国内の各社が探鉱開発を行なつた海外鉱山は，いず 